\title{
D. E. Garner, D. L. McKee and Y. A. McKee, Accounting and the Global Economy after Sarbanes-Oxley
}

\author{
M.E. Sharpe Inc, Armonk, 2007, 272 pp, \$68.95, \\ ISBN: 978-0-7656-1376-9
}

\section{David B. Smith}

Published online: 24 July 2008

(C) Springer-Verlag 2008

I found the book to be an interesting discussion about issues surrounding the passing of the Sarbanes-Oxley Act of 2002 (SOX) and some of the trends shaping the accounting profession in the post-SOX era. The book touched upon a number of interesting topics such as (1) the problems leading to the fall of Arthur Andersen, (2) a brief history of the rise in importance of International Reporting Standards (IFRS), (3) problems with competition in the audit industry, and (4) the implication of the increase in the number of misstatements.

I did think the book suffered from several deficiencies. First, I think the authors missed an opportunity in the introduction to focus more on quality control and ethical problems related to all the Big Five audit firms in the pre-SOX period rather than concentrating on Arthur Andersen. For example, the KPMG tax practice problems, the PricewaterhouseCooper independence issues, and the Ernst and Young audit problems showed that problems in the accounting industry were not limited to Arthur Andersen even though only Arthur Andersen was ultimately destroyed. The authors' discussion of these issues in latter chapters provided an important prospective to the pre-SOX state of the accounting profession. Second, the book could have been a little better organized and could have been substantially shortened since a number of topic areas overlapped.

I think the book would be a useful addition to an accounting theory class looking at future trends in accounting and auditing. It would also be interesting reading for accounting practitioners interested in an overview of changes in accounting after SOX.

D. B. Smith $(\bowtie)$

School of Accountancy, University of Nebraska-Lincoln, P.O. Box 880488, Lincoln,

NE 68588-0488, USA

e-mail: dsmith19@unl.edu 